\title{
UJI AKTIVITAS ANTIJAMUR MINYAK ATSIRI BAWANG BOMBAY (Allium cepa L.) TERHADAP Pseudomonas aeruginosa
}

\author{
Miftahur Rahmi ${ }^{1^{*}}$, Tisa Mandala Sari ${ }^{\mathbf{x}^{*}}$, Agustri Melia ${ }^{1^{*}}$ \\ Sekolah Tinggi Farmasi Indonesia Yayasan Perintis Padang
}

\begin{abstract}
Onions (Allium cepa L) contain essential oils which contain sulfur in the form of isothiocyanates or thiosulfinates which are known as antibacterial and antifungal. The aims of this study was to determine the antibacterial activity and minimum inhibitory concentration (MIC)of essential oils from onions (Allium cepa $\mathrm{L}$ ) against Pseudomonas aeruginosa. This research was an experimental study using the Kirby-bauer method using discs. The results were obtained by concentration of $20 \%(\mathrm{C} 1), \quad 10 \%(\mathrm{C} 2), \quad 5 \%(\mathrm{C} 3), \quad 2,5 \%(\mathrm{C} 4), \quad 1,25 \%(\mathrm{C} 5), \quad 0,625 \%(\mathrm{C} 6)$, and $0,312 \%(\mathrm{C} 7)$ provide the inhibition with an average diameter are 14,94 $\mathrm{mm}, 14,17 \mathrm{~mm}, 13,62 \mathrm{~mm}$, $12,97 \mathrm{~mm}, 11,97 \mathrm{~mm}, 9,11 \mathrm{~mm}$ and $0 \mathrm{~mm}$. From this research it can be concluded that essential oils from onions (Allium cepa L) can inhibit the growth of Pseudomonas aeruginosaand the minimum inhibitory concentration (MIC) of essential oils from onions (Allium cepa L) against Pseudomonas aeruginosawas at a concentration of $0,612 \%$ (C6) with an average diameter of 9,11 $\mathrm{mm}$
\end{abstract}

Keyword : Onions (Aliium cepa L), Minimum Inhibitory Concentration (MIC), Pseudomonas aeruginosa, Thiosulfinates, Disc Diffusion.

\section{PENDAHULUAN}

Manusia hidup di alam selalu kontak dengan mikroorganisme, bakteri, virus, fungi, dan berbagai bentuk kehidupan parasit. Infeksi terjadi bila mikroorganisme yang masuk ke dalam tubuh menyebabkan berbagai gangguan fisiologi normal tubuh sehingga timbul penyakit infeksi. Penyakit infeksi mempunyai kemampuan menular pada orang lain yang sehat sehingga populasi penderita dapat meluas (Wattimena dkk., 1991).

Pseudomonas aeruginosa dapat berada dalam orang sehat, dimana bersifat saprofit. Bakteri ini menjadi patogenik hanya jika berada pada tempat dengan daya tahan tidak normal, misalnya diselaput lendir dan kulit yang rusak akibat kerusakan jaringan (Brooks et al., 2005). Pseudomonas aeruginosa dari bentuk koloni berbeda mungkin juga mempunyai aktivitas biokimia dan enzimatik yang berbeda, dan memberi kepekaan yang berbeda terhadap zat antimikroba.

Salah satu tumbuhan berkhasiat obat yang digunakan oleh masyarakat adalah bawang bombay (Allium cepa L.). Bawang bombay merupakan salah satu tumbuhan penghasil minyak atsiri. Minyak atsiri yang dihasilkan bawang bombay mengandung komponen senyawa sulfur yang disebut thiosulfinates atau isothiocyanates. Senyawa ini sangat reaktif, mudah menguap, berbau khas dan dapat memicu pengeluaran air mata. Beberapa penelitian sebelumnya yang dilakukan oleh Benkeblia and Lanzotti (2007), Benkeblia (2004) dan KocicTanackov et al., (2009) membuktikan bahwa thiosulfinates memiliki aktivitas antibakteri dan antijamur.

Penelitian Putri (2014) menunjukkan adanya aktivitas antibakteri dari minyak atsiri bawang bombay terhadap MethicillinResistant Staphylococcusaureus (MRSA) secara in vitro. Aktivitas antibakteri ditunjukkan pada konsentrasi 5\%, 10\% dan $15 \%$ dengan diameter zona hambat $11,2 \mathrm{~mm}$, $14,2 \mathrm{~mm}$ dan $17,2 \mathrm{~mm}$. Penelitian Wuryanti (2009) juga menunjukkan adanya aktivitas antibakteri ekstrak bawang bombay terhadap Pseudomonas aeruginosa, ditunjukkan pada konsentrasi $40 \%, 60 \%, 80 \%$ dan $100 \%$ dengan diameter daya hambat $3,5 \mathrm{~mm}, 4,5$ $\mathrm{mm}, \quad 6,5 \mathrm{~mm}$ dan 7,5 mm.Berdasarkan penelitian tersebut maka peneliti tertarik melakukan penelitian untuk mengetahui aktivitas antibakteri dari minyak atsiri 
bawang bombay (Allium cepa L.) terhadap Pseudomonas aeruginosa.

Berdasarkan penelitian tersebut maka peneliti tertarik melakukan penelitian untuk mengetahui aktivitas antibakteri dari minyak atsiri bawang bombay (Allium cepa L.)dan mengetahui Konsentrasi Hambat Minimum (KHM) terhadap Pseudomonas aeruginosa dengan konsentrasi $0,3125 \%, \quad 0,625 \%$, $1,25 \%, 2,5 \%, 5 \%, 10 \%, 20 \%$ dan kontrol negatif DMSO.

Penelitian ini secara umum bertujuan untuk untuk mengetahui aktivitas antibakteri minyak atsiri bawang bombay (Allium cepa L.) dan dan mengetahui Konsentrasi Hambat Minimum (KHM) terhadap Pseudomonas aeruginosa yang ditunjukkan oleh pembentukan daerah bening pada media bakteri uji. Selain itu, penelitian ini dapat memberikan informasi tentang manfaat minyak atsiri bawang bombay (Allium cepa L.) yang memiliki aktivitas antibakteri terhadap Pseudomonas aeruginosa.

\section{METODE PENELITIAN}

\section{Waktu dan Tempat Penelitian}

Penelitian ini merupakan penelitian eksperimental. Penelitian ini dilaksanakan selama 3 bulan dari bulan Desember 2018 Februari 2019 destilasi dilakukan di Laboratorium Kimia Universitas Negeri Padang, pemeriksaan fisik minyak atsiri dilakukan di Laboratorium KBA STIFI Yayasan Perintis Padang dan uji aktivitas antibakteri dilakukan di Laboratorium Mikrobiologi Fakultas Kedokteran Universitas Andalas Padang.

\section{Alat dan Bahan}

Alat-alat yang digunakan dalam penelitian ini adalah alat destilasi, cawan petri kering dan steril,cotton swab steril, botol semprot, beaker glass, vortex mixer, refraktometerAbbe, timbangan analitik digital, cawan penguap,oven, kertas cakram, gelas ukur, perkamen, pipit mikro, pipet tetes, mikro cup, pinset, spatel, piknometer, corong pisah, vial, kaca arloji, penjepit, inkubator, autoklaf, lampu spritus, jarum ose, kapas steril, koran, tisu dan tabung reaksi beserta raknya.

Bahan-bahan yang digunakan adalah bawang Bombay (Allium cepa L.) yang diperoleh dari Alahan Panjang Kabupaten Solok, etanol 96\%, media Muller Histon agar (MHA), Dimetil sulfoxide (DMSO), aquadest steril, biakan bakteri Pseudomonas aeruginosa, $\mathrm{NaOH}, \mathrm{Pb}$ Asetat, Natrium Sulfat Anhidrat dan larutan $\mathrm{NaCl}$ fisiologis $0,9 \%$. Isolasi Minyak Atsiri Bawang Bombay
dengan Metode Destilasi Air

Pembuatan minyak atsiri Bawang bombay (Allium cepa L.) dilakukan di Laboratorium Kimia Universitas Negeri Padang. Bawang bombay yang telah dibersihkan dan ditimbang sebanyak $20 \mathrm{~kg}$, diambil dari Alahan Panjang kab. Solok, Kemudian dilakukan perajangan pada bawang bombay dan diblender. Potongan bawang bombay dimasukkan tambahkan air sampai seluruh sampel terendam sempurna didalam labu. Labu dihubungkan dengan perangkat alat destilasi air. Destilasi dilakukan selama 4-5 jam. Destilat ditampung dalam corong pisah dan dipisahkan minyak dari air. Kemudian minyak atsiri yang diperoleh ditambahkan natrium sulfat anhidrat untuk menghilangkan air yang masih ada dalam minyak atsiri. Proses pengeringan ini dilakukan dalam suhu kamar.

\section{Pembuatan Konsentrasi Minyak Atsiri}

Minyak atsiri diencerkan dengan DMSO sehingga mencapai konsentrasi uji $20 \%, \quad 10 \%, \quad 5 \%, \quad 2,5 \%, \quad 1,25 \%, \quad 0,625 \%$, $0,312 \%$.

\section{Pemeriksaan Minyak Atsiri Bawang Bombay (Allium cepaL.)}

\section{a. Organoleptis}

Pengamatan dilakukan secara visual dengan mengamati bentuk, warna, bau, dan rasa (Depkes, 1979).

\section{b. Pemeriksaan Kelarutan}

Pemeriksaan kelarutan menurut Farmakope Indonesia edisi III dilakukan di dalam pelarut aqua destilata dan etanol 96\%. Sebanyak $1 \mathrm{~g}$ minyak atsiri Bawang bombay (Allium cepa L) dilarutkan ke dalam aqua destilata dan dalam etanol 96\% (Depkes, 1979).

\section{c. Indeks Bias}

Indeks bias diukur dengan menggunakan Refraktometer Abbe pada suhu $\pm 25^{\circ} \mathrm{C}$. Cara : alat ditempatkan sedemikian rupa, dibersihkan kaca prisma dengan kapas yang telah dibasahi dengan alkohol dan 
dikeringkan. Minyak diteteskan dari tepi kaca prisma dengan hati-hati, tutup dan dibiarkan beberapa saat. Dilakukan pembacaan dengan memutar alidade mundur atau maju sampai bayangan bidang berubah dari terang menjadi gelap. Diatur garis pembatas sehingga diperoleh warna yang mantap sehingga didapatkan nilai indeks bias (Depkes RI, 1995 ; Guenther, 1987).

\section{d. Bobot Jenis}

Menentukan bobot jenis minyak dilakukan dengan menggunakan piknometer kosong, bersih, kering, dan telah dikalibrasi.Cara : ambil piknometer yang sudah diketahui volumenya yaitu (a). Berat piknometer kosong dinyatakan dengan nilai (b). Isi piknometer dengan minyak atsiri bawang bombay dan timbang, beratnya dinyatakan dengan nilai (c), pastikan tidak ada rongga udara pada tutup piknometer (Depkes RI, 1995 ; Guenther, 1987).

$$
\text { Rumus }: \mathrm{Bj}=\frac{\mathrm{c}-\mathrm{b}}{\mathrm{a}}
$$

Keterangan:

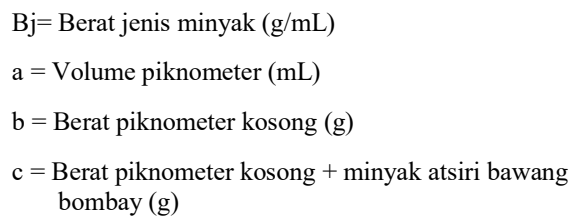

\section{e. Uji Sulfur}

Minyak atsiri bawang bombay (Allium cepa L) sebanyak $1 \mathrm{ml}$ ditambah dengan $1 \mathrm{ml} \mathrm{NaOH} 6 \mathrm{M}$

kemudian dipanaskan selama 1 menit dengan menggunakan spritus, setelah itu tambahkan 1 tetes $\mathrm{Pb}$ asetat. Larutan yang positif mengandung gugus belerang ditandai dengan perubahan warna ataupun endapan berwarna hitam. (Hawab, 2004).

\section{f. Rendemen}

$\%$ Rendemen $=\frac{\text { Berat minyak diperoleh }}{\text { Berat Bawang segar }} \times 100 \%$

\section{Pengujian Anti Bakteri}

Pengujian antibakteri menggunakan metode difusi (Kirby - bauer). Media MHA yang telah dipanaskan, diambil dimasukkan kedalam cawan petri, dibiarkan sampai memadat. Ambil suspensi bakteri yang telah dibandingkan kekeruhannya dengan Mc. Farland 0,5\% menggunakan cotton swab steril, kemudian diratakan ke permukaan agar. Setelah itu diambil $10 \mu 1$ minyak atsiri bawang bombay pada masing - masing konsentrasi dan diteteskan diatas kertas cakram. Sebagai kontrol negatif digunakan DMSO.Kemudian, letakkan kertas cakram di atas permukaan agar menggunakan pinset. Selanjutnya, diinkubasi selama 24 jam pada suhu $37{ }^{\circ} \mathrm{C}$. Amati pertumbuhan bakteri dan ukur diameter zona hambat (Clear Zone)yang terbentuk ditandai dengan adanya daerah jernih disekeliling kertas cakram, catat hasil pengukuran. Prosedur ini dilakukan 3 kali pengulangan.

\section{HASIL DAN PEMBAHASAN}

Hasil destilasi umbi lapis bawang bombay (Allium cepa L.) menggunakan metode destilasi air diperoleh $12,1 \mathrm{ml}$ minyak atsiri. Hasil pemeriksaan fisik minyak atsiri bawang bombay (Allium cepa L.)dapat dilihat pada Tabel 1.

Tabel 1. Hasil pemeriksaan fisik minyak atsiri bawang bombay (Allium cepa L.)

\begin{tabular}{|l|l|l|}
\hline No. & Pemeriksaan & Hasil pengamatan \\
\hline 1. & Organoleptis & \\
& - Bentuk & - Cairan \\
& - Warna & - Kuning pucat \\
& - Bau & - Bau khas bawang bombay \\
& - Rasa & - Hambar dan segar \\
\hline 2. & Rendemen & $0,067 \%$ \\
\hline 3. & Berat Jenis & $0,98126 \mathrm{~g} / \mathrm{Ml}$ \\
\hline
\end{tabular}




\begin{tabular}{|l|l|l|}
\hline 4. & Kelarutan & \\
& $\begin{array}{l}\text { - Dalam etanol 96\% } \\
\text { - Dalam aquadest }\end{array}$ & - Larut \\
& - Tidak larut \\
\hline 5. & Indeks bias & 1,55 \\
\hline 6. & Uji sulfur & Endapan hitam \\
\hline
\end{tabular}

Rendemen minyak atsiri bawang bombay (Allium cepa L.) yang didapatkan sebesar $0,067 \%$. Hasil ini jauh lebih kecil bila dibandingkan dengan yang dilaporkan oleh Putri (2014) yaitu sebesar 0,1\%. Hal ini dapat disebabkan oleh beberapa faktor tertentu seperti faktor lingkungan yaitu tempat tumbuh, nutrisi dan pengaruh cahaya, varietas dari bawang bombay (Allium cepa L.). Faktor lainnya adalah suhu selama penyulingan. Semakin tinggi suhu, rendemen minyak atsiri juga semakin tinggi (Saputra, 2013).Pengaruh besarnya suhu pemanasan pada minyak atsiri juga berbanding terbalik terhadap waktu yang dibutuhkan. Selain itu, lamanya proses penyulingan serta ukuran partikel juga mempengarui jumlah rendemen yang diperoleh (Saputra, 2013).

Pada hasil pemeriksaan organolepstis, diketahui bahwa bawang bombay (Allium сера L.) berbentuk cair, berwarna kuning pucat, berbau khas bawang bombay serta berasa hambar dan segar.

Pada pemeriksaan kelarutan minyak atsiri bawang bombay (Allium cepa L.) diketahui bahwa $1 \mathrm{ml}$ minyak atsiri bawang bombay (Allium cepa L.) larut dalam $1 \mathrm{ml}$ etanol 96\%. Menentukan kelarutan minyak tergantung juga kepada kecepatan daya larut dan kualitas minyak. Semakin mudah larut minyak dalam etanol maka semakin banyak kandungan senyawa polar dalam minyak (Susetyo dan Reny, 2004).

Pada pemeriksaan uji sulfur minyak atsiri bawang bombay (Allium cepa L.) didapatkan hasil positif, ditandai dengan adanya perubahan warna(endapan berwarna hitam). Penambahan $\mathrm{NaOH}$ pada minyak atsiri yang dipanaskan selama 1 menit bertujuan untuk melihat perubahan kandungan $\mathrm{S}$ organik sehingga menjadi $\mathrm{NaS}$ saat berikatan dengan Na. Minyak atsiri kemudian ditambah $\mathrm{Pb}$ asetat sehingga terbentuk $\mathrm{PbS}$ yang terlihat sebagai endapanhitam (Hawab, 2004). Hal ini menunjukkan bahwa hasil uji sulfur minyak atsiri bawang bombay dinyatakan positif mengandung sulfur. dilakukan dengan alat Refraktometer abbepada suhu $25^{\circ} \mathrm{C}$ sebesar 1,55. Nilai indeks bias bergantung pada jumlah nilai karbon dan jumlah ikatan rangkap (Susetyo dan Reny, 2004). Hal ini diartikan bahwa indeks bias dipengaruhi komponen penyusun minyak atsiri. Semakin panjang rantai karbon dan semakin banyak ikatan rangkap dalam minyak atsiri maka semakin besar pula indeks biasnya. Serta semakin pekat warna minyak atsiri diduga mempengaruhi nilai indeks bias. Semakin tinggi nilai indeks bias menunjukkan bahwa minyak atsiri memiliki kualitas yang baik.

Pada pemeriksaan bobot jenis minyak atsiri bawang bombay (Allium cepa L.) dilakukan dengan menggunakan piknometer didapatkan hasil $0,98126 \mathrm{~g} / \mathrm{mL}$. Komposisi minyak dari jenis yang sama akan berbeda jika tanaman penghasil minyak ditanam pada daerah yang berbeda. Sebab setiap daerah yang berbeda akan mempunyai iklim, keadaan tanah, lingkungan tempat tumbuh, dan ketinggian dari permukaan laut yang berbeda pula (Haris, 1987).

Hasil pengujian aktivitas antijamur dan Konsentrasi Hambat Minimum (KHM) minyak atsiri bawang bombay (Allium cepa L.) terhadap pertumbuhan Pseudomonas aeruginosaini yang memberikan daerah hambat adalah pada konsentrasi minyak atsiri $20 \% \quad(\mathrm{C} 1), \quad 10 \% \quad(\mathrm{C} 2), \quad 5 \% \quad$ (C3), 2,5\% (C4), $1,25 \% \quad$ (C5), $0,625 \% \quad$ (C6)dengan diameter rata - ratasebesar 14,94 $\mathrm{mm}, 14,17$ $\mathrm{mm}, 13,62 \mathrm{~mm}, 12,97 \mathrm{~mm}, 11,97 \mathrm{~mm}, 9,11$ mm. Sedangkan pada konsentrasi dan $0,312 \%$ (C7) tidak memberikan respon daerah hambat, sama halnya pada kontrol negatif (DMSO) juga tidak memberikan respon daerah hambat. Hal ini berarti semakin besar konsentrasi yang digunakan maka semakin besar pula daerah hambat yang diberikan.

Hasil pengukuran diameter daya hambat yang terbentuk dibandingkan dengan klasifikasi respon hambatan pertumbuhan mikroba pada tabel klasifikasi respon hambatan pertumbuhan mikroba menurut Clinical and Laboratory Standart Institute 
(CLSI) dimana diameter $>20 \mathrm{~mm}=$ kuat, 15$19 \mathrm{~mm}=$ sedang, dan $<14 \mathrm{~mm}=$ lemah. Berdasarkan tabel ini seluruh daerah hambat yang diperoleh dari penelitian ini termasuk pada katagori lemah.

Terbentuknya daerah hambat terhadap Pseudomonas aeruginosa disebabkan oleh adanya zat aktif dari minyak atsiri bawang bombay (Allium cepa L.) yang diketahui memiliki aktivitas antibakteri dan antijamur. Zat aktif yang terkandung dalam minyak

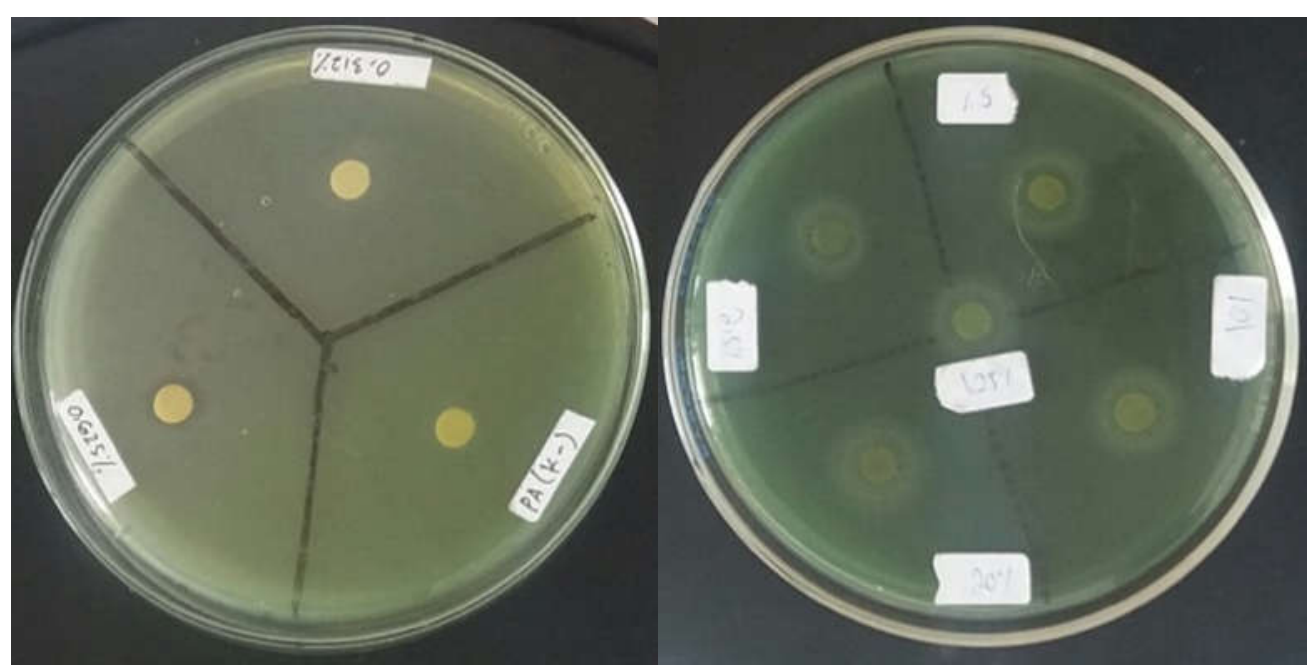

Gambar 1. Diameter Daya Hambat antibakteri Minyak Atsiri Bawang Bombay (Allium cepa L.)

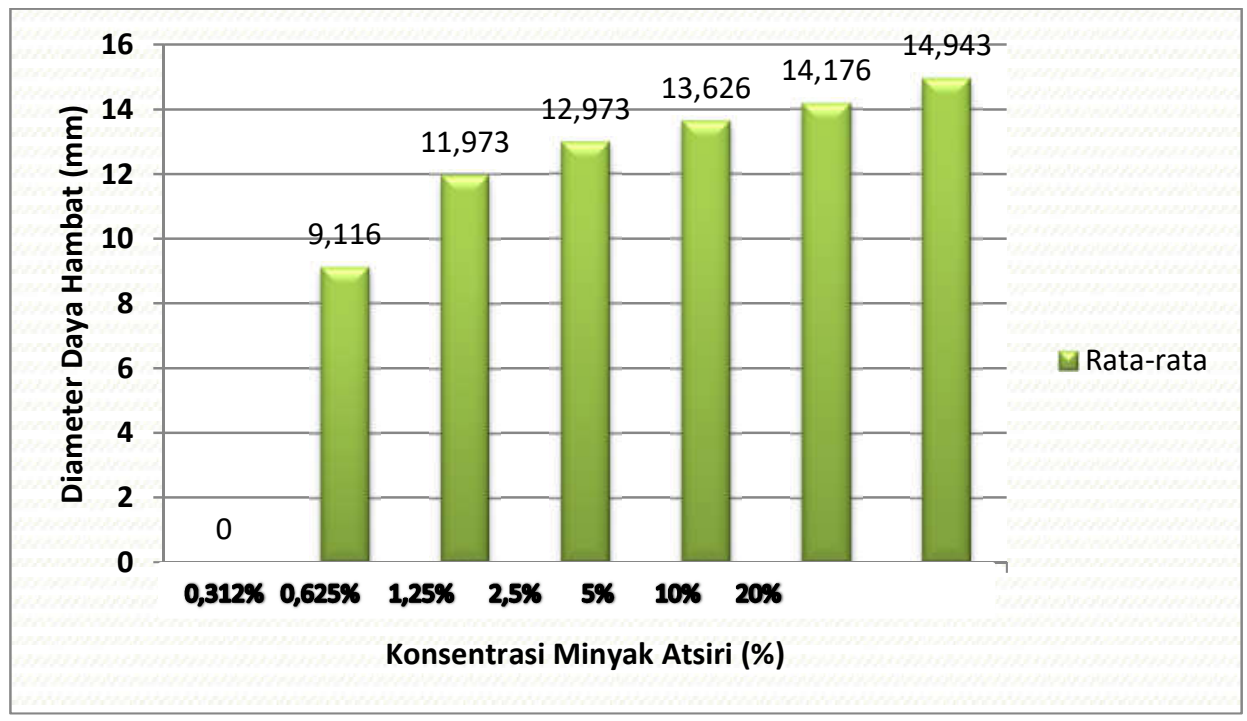

Gambar 2. Grafik Konsentrasi Hambat Minimum (KHM) Minyak Atsiri Bawang Bombay (Allium cepa L.) terhadap Pseudomonas aeruginosa

$\begin{array}{lccr}\text { Dari } & \text { hasil } & \text { pengujian } & \text { aktivitas } \\ \text { antibakteri } & \text { dan } & \text { konsentrasi } & \text { hambat } \\ \text { minimum } & \text { (KHM) } & \text { minyak atsiri } & \text { bawang }\end{array}$

bombay (Allium cepa L.) yang dilakukan terhadap Pseudomonas aeruginosa, diperoleh hasil bahwa pada minyak atsiri 
bawang bombay (Allium cepa L.) memberikan aktivitas terhadap Pseudomonas aeruginosa dan konsentrasi hambat minimum yaitu berada pada konsentrasi 0,612\% (C6) sebesar 9,11 mm. Karena pada konsentrasi $0,612 \%$ (C6) terbentuk daerah hambat sedangkan konsentrasi dibawahnya yaitu pada konsentrasi $0,312 \%$ (C7) tidak terbentuk daerah hambat lagi.

\section{SIMPULAN}

Berdasarkan hasil penelitian yang telah dilakukan dapat disimpulkan bahwa :

1. Minyak atsiri bawang bombay (Allium cepa L.) memiliki aktivitas antibakteri terhadap Pseudomonas aeruginosa.

2. Konsentrasi hambat minimum (KHM) minyak atsiri bawang bombay (Allium cepa L.) terhadap Pseudomonas aeruginosa berada pada konsentrasi 0,612\% (C6) dengan diameter sebesar $9,11 \mathrm{~mm}$.

\section{SARAN}

Disarankan kepada peneliti selanjutnya untuk memformulasikan minyak atsiri bawang bombay (Allium cepa L.) sebagai sediaan topikal antibakteri dan malakukan skrining lebih lanjut mengenai komponen zat aktif minyak atsiri bawang bombay (Allium cepa L .).

\section{DAFTAR PUSTAKA}

Benkeblia N. 2004. Antimicrobial Activity of Essential Oil Extracts of Various Onions (Allium cepa) and (Allium sativum). Lebensm. Wiss. U. Technol.

Benkeblia N and Lanzotti V. 2007. Allium Thiosulfinates: Chemistry, Biological Properties and Their Potential Utilization in Food Preservation. Food. 1(2): p. 193 - 201.

Brooks, G.F., Butel, J.S. and Morse, S.A. 2005. Medical Microbiology. Mc Graw Hill. New york.
Brooks, G. F., J. S. Butel and S. A. Morse, Jawetz, Melnick And Adelberg's. 2005. Mikrobiologi Kedokteran2 (Edisi I). Diterjemahkan oleh N. Widorini. Jakarta : Salemba Medika.

Chun L.H, Dai D.H, Wei L.H. 2012. Antimicrobial and Antioxidant Activities of Essential Oil From onion. Food Control. 30:48-53

Depkes RI. 1979. Farmakope Indonesia. Edisi III. Jakarta : Departemen Kesehatan RI. Hal. 813.

Depkes RI. 1995. Materia Medika Indonesia. Edisi VI. Jakarta : Departemen Kesehatan Republik Indonesia. Hal. 72-76.

Guenther, E. 1987. Minyak Atsiri Jilid I (Terjemahan). Jakarta : Universitas Indonesia Press.

Haris, R. 1987. Tanaman Minyak Atsiri. Jakarta : Penerbit Penebar Swadaya.

Hawab H. 2004. Pengantar Biokomia .Jakarta : Bayu Media Publishing; p. 43.

Kocic-Tanackov SD, Dimic GR, Tepic AN, Vujicic BL. 2009. Influence of Allium ampeloprasum L. and Allium cepa L. Essential Oils on the Growth of Some Yeast and Moulds. Proc. Nat. Sci. 116:p. $121-30$.

Putri, E., R. 2014. Uji Daya Hambat Minyak Atsiri Bawang Bombay (Allium Cepa L.) Terhadap Pertumbuhan Methicillin - Rn resistant Staphylococcus Aureus (Mrsa) Rn secara In Vitro. Banda Aceh : Universitas Syiah Kuala.

Saputra, Rizki Adik. 2013. Pengaruh pengaturan Suhu Penyulingan terhadap Rendemen Minyak Atsiri dan Kadar Senyawa Diallyl Sulfida dalam Minyak Atsiri Bawang Putih (Allium sativum). Thesis. Universitas Brawijaya.

Susetyo R., dan Reny H. 2004. Kiat Menghasilkan Minyak Sereh Wangi. Jakarta : Penebar Swadaya.

Wattimena, J. R., Nelly C. Sugiarso, Mathilda B. Widianto, Elin Y. Sukandar, Andreanus A. Soemardji, Anna R. Setiadi. 1991. Farmakodiamik dan Terapi Antibiotik. Yogyakarta : Gadjah Mada University Press. 19-23.

Wuryanti dan Murnah. 2009. Uji Ekstrak Bawang Bombay terhadap Antibakteri gram negatif Pseudomonas aeruginosa dengan metode difusi cakram. Jurnal Sains \&Matematika (JSM). Vol. 17 No. 3. UNDIP. 